
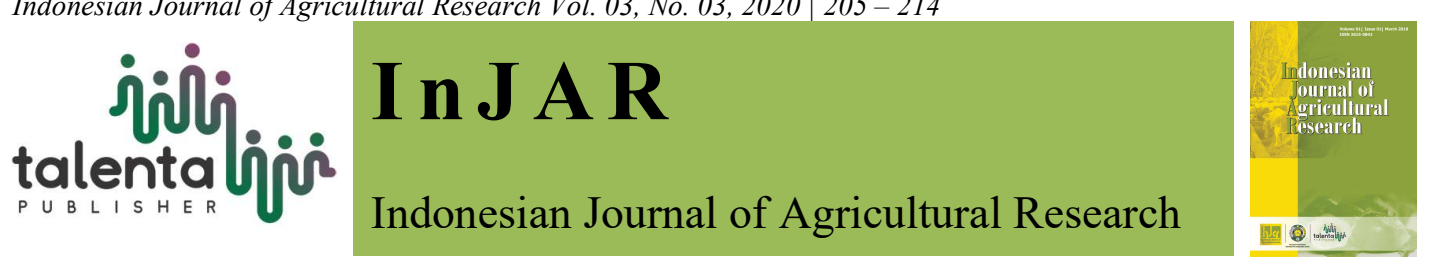

\title{
Analysis of The Cost and Economic Returns in Rice Production in Ebonyi State, Nigeria
}

\section{Ogechi Cordelia Nwahia}

Department of Agricultural Economics, Faculty of Agriculture, Ahmadu Bello University, Zaria, Nigeria

\begin{abstract}
Low profit from most staple food production in Nigeria, have continued to discourage the teaming unemployed Nigerian youth from taking up farming as a business. Therefore, this study analyzes the cost and economic returns in Ebonyi State rice production. This study made used of simple random sampling techniques to select 242 rice farmers. The study employed the use of structured questionnaire in its primary data collection. The collected data were analyzed using descriptive statistics (Percentages, Frequency, Standard deviation and Mean), Net Rice Farming Income (NRFI) and Returns/US Dollar Invested (RUSDI). The result from the analysis reveals that rice production is profitable in Ebonyi state. The Net Rice Farming Income (NRFI) obtained by the farmers in Ebonyi state were $\$ 900.10$ US Dollar per hectare while the return on investment obtained by them were $\$ 2.90$ US Dollar per hectare. Therefore, unemployed youth in Nigeria should be encourage through provision of rice farming grant or loan by the government. In addition, adequate training on improve technology should be conducted by the government agency for the rice farmers.
\end{abstract}

Key Words: net farm income (nfi), profitability, rice farmers, rice production, returns per us dollar invested

\section{Introduction}

Rice is among the important staple foods in Nigeria, and different agro-ecological zones in Nigeria is favourable for rice production [1]. Nigeria has a good soil and climatic condition suitable for rice production, these implies that rice can grow everywhere in Nigeria. Despite these potentials, the country produces only 3.2 million tonnes of paddy annually [2] [3]. However, compared to the annual consumption level of 5.2 million tonnes, the above estimate is far below the national requirement, since an average Nigerian currently consumes $40 \mathrm{~kg}$ of rice per year [4]. Nigeria is ranked as the largest importer of rice in West Africa, and among the highest rice importer in the world [5]. Recently, Nigeria is among the countries with large volume of rice importation [3].

\footnotetext{
*Corresponding author at: Department of Agricultural Economics, Faculty of Agriculture, Ahmadu Bello University, Zaria, Nigeria

E-mail address: godstime_ogefine@yahoo.com
} 
Nigerian government have made efforts to increase local rice production, among such efforts includes, Presidential Rice Initiative of 1999; Multinational Rice Dissemination Project (MNRDP) of 2000; Ibom Rice Project of 2001; National Rice Development Strategy; USAIDMARKETS of 2005, among others. But rice production failed to keep pace with the growing domestic demand. United States Department of Agriculture (USDA) reported that Nigeria local rice production dropped in 2016 and 2018 compared with 2015 production [6]. Studies have proved that rice demand will continue to grow in Nigeria, as a result of rapid growth in Nigerian population [7].

The demand for rice was 5.9 million metric tonnes (MT) in 2014, but Nigeria produced only 2.7 million MT, a gap of 3.2 Million MT was left out [8]. In 2017, the demand for rice in Nigeria increased to 6.3 million MT [9]. The need to bridge the gap between the demand for rice and supply of rice led Nigerian government into rice importation. In 2013, Nigeria spent $\$ 6,243,366.42$ daily on rice importation [5]. There is a need for Nigerian farmers to utilize this opportunity in the rice sector and strive to bridge the gap between demand and supply.

Most rice farmers in Nigeria operate in a small scale. Thus, the farmers are unable to maximize production in order to obtain the corresponding returns [10]. This is because the production resources in rice production are expensive and inadequately available to support its commercial production [10]. The small-scale farmers are faced with the problems of scarcity of capital, labour, and agricultural land. Occasionally, with the problem of climate change resulting in floods, droughts, erosion, forest fire. In addition, the farmers are faced with the problem of low soil fertility, pests and diseases and low crop yields [11] - [14]. Thus, the small-scale farmers are not profit efficient [1]. Low rice profitability is a problem which discourages the Nigerian farmer from embarking into rice production. Therefore, this study tends to analyze the cost and economic returns in Ebonyi State rice production, and as such, the following research questions were set: (i) What is the socio-economics profile of Ebonyi rice farmers? And (ii) What is the cost and returns in rice production by the rice farmers?

\section{Research Methodology}

The study area is Ebonyi State. Ebonyi State is among the states in Nigeria with land area of about $5,935 \mathrm{~km}^{2}$ [15]. Eighty-five percent of Ebonyi people has agriculture as their major occupation. Abakaliki rice production is among the agricultural potentials in Ebonyi State. Abakaliki rice is cultivated in a land area of 311,208 hectares by over 140 thousand farmers [16]. The rainfall in Ebonyi State spreads between April and November with July and September as its peak. Total annual mean rainfall is $1750 \mathrm{~mm}$ with temperature that ranges from $27^{\circ} \mathrm{C}$ to $31^{\circ} \mathrm{C}$ for night and day temperatures respectively. Relative humidity is usually high at $80 \%$ during rainy season and declines during the dry season to less than $65 \%$. Ebonyi State is within latitude $7^{0} 30 \mathrm{E}$, 
and $8^{0} 30 \mathrm{E}$, and longitude $6^{\circ} 40 \mathrm{~N}$, and $6^{\circ} 45 \mathrm{~N}$ of South East zone of Nigeria. Ebonyi has 13 (thirteen) Local Government Areas with 3.1 million people in population.

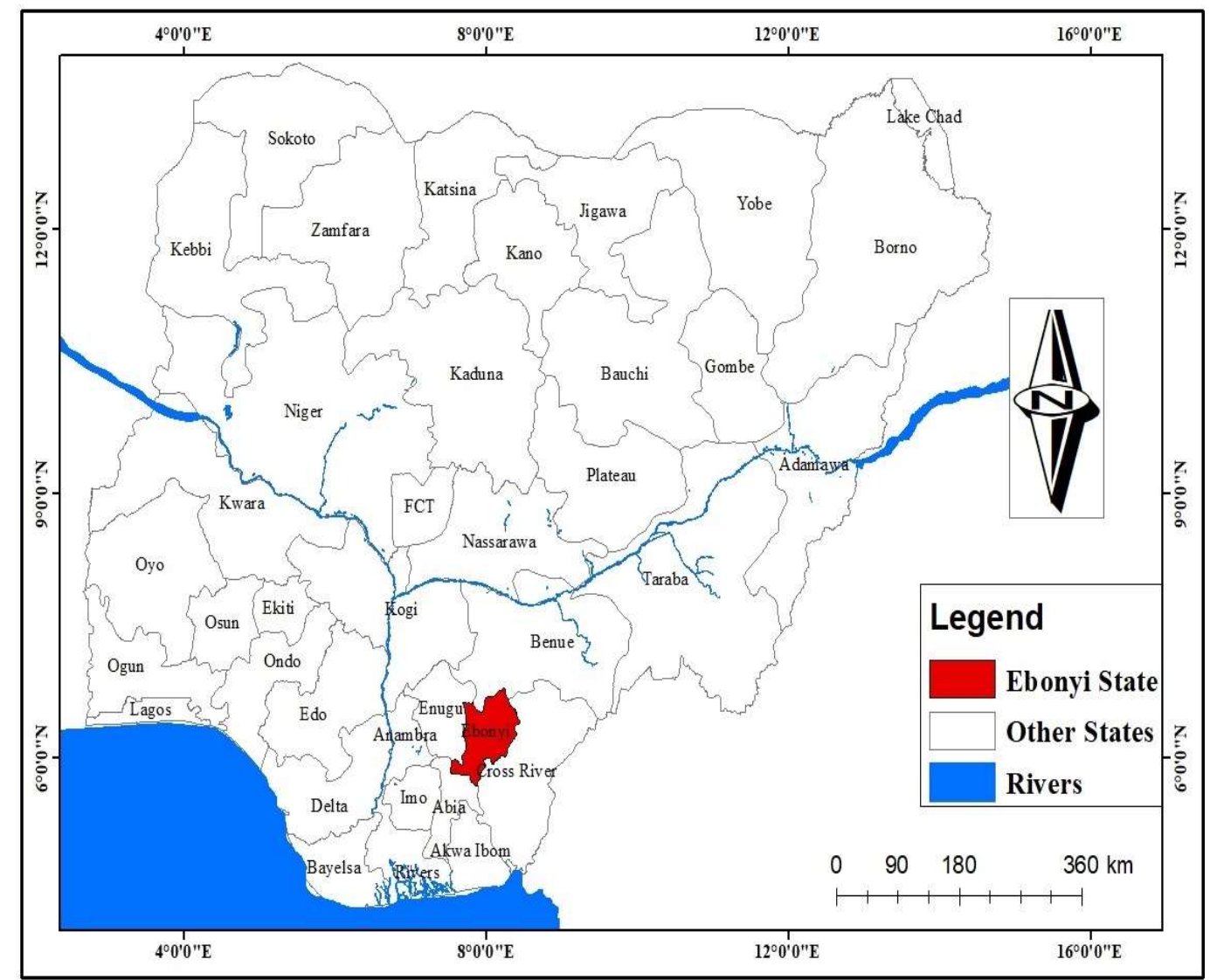

Source: Administrative map of Nigeria

MAP OF NIGERIA SHOWING EBONYI STATE

Figure1. Map of Nigeria Showing Ebonyi State

\subsection{Collection of the Data and Sampling Technique}

Simple sampling technique was used in this study. First, 4 Local Government Areas out of 13 in Ebonyi State were randomly selected. Secondly, 3 communities each from the Local Government Areas were randomly selected. The 3 communities (selected on equal proportion basis) captured about $10 \%$ of the total communities in each of the Local Government Areas. This is in line with [17] who posited that $\geq 10 \%$ of the population is a fair representation especially where there is a large population. The randomization procedure adopted involved writing the names of the LGAs/communities on cards, the cards were put into a box and reshuffle thoroughly and then drawn without replacement, this ensures that each one was given equal opportunity of being selected. Thirdly, using the Slovian scientific formula (1967) adopted by [18] for calculating sample size, 242 rice farmers were selected randomly for the study.

The Slovian scientific formula is given as $\mathrm{n}=\frac{N}{1+N\left(e^{2}\right)}$, Where $\mathrm{n}$ is the size of the sample, $\mathrm{N}$ is sample frame, and $e^{2}$ is the significant level desired (the study used 0.05 ). The study data were 
collected from primary source with structured questionnaire. Structured questionnaire was used to collect primary data for the study. Data were analyzed with descriptive statistics (Percentage, Frequency, Standard Deviation (S.D) and Mean), Net Rice Farming Income (NRFI), and Returns/US Dollar Invested (RUSDI).

\subsection{Model for Net Rice Farming Income (NRFI)}

Net income is a statement that shows the revenue and expenses incurred in a business within one year. The estimation of the difference between the revenue and expenses incurred in rice business by the farmers were done using Net Rice Farming Income. A Positive value of NRFI shows that rice business is profitable while a negative value shows a loss in the business. [19] approach was used in rice production profitability calculation. The total cost of rice production is the addition of total variable and total fixed costs. The total variable cost in this study are rice seeds cost, fertilizers cost, herbicide cost, labour cost, and working capital interests while the total fixed cost includes land payment and depreciation on farm implements.

Net Rice Farming Income (NRFI) is the value that remains after subtraction of total production cost from the gross income realized and total farming cost as showed below:

Net Rice Farming income $(\mathrm{NRFI})=\mathrm{GI}-\mathrm{TPC}$

where GI $=$ gross income (total paddy value in US Dollar); TPC $=$ total production cost

$$
\mathrm{TPC}=\mathrm{TFC}+\mathrm{TVC}
$$

where $\mathrm{TFC}=$ total fixed cost and $\mathrm{TVC}=$ total variable cost

\subsection{Model for Returns/Dollar Invested (RUSDI)}

$$
\text { Returns/US Dollar invested (RUSDI) }=\frac{T R}{T C}
$$

where RUSDI $=$ Returns/US Dollar invested; $\mathrm{TR}=$ Total revenue in US Dollar; $\mathrm{TC}=$ Total cost of rice production in US Dollar

When RUSDI is below one, it shows that embarking on the investment at the present price and production level is not profitable. If RUSDI is more than one, it means that embarking on the investment at the present price and production level is profitable. If RUSDI is equal to one, it shows that embarking on the investment at the present price and production level is neither unprofitable nor profitable.

\section{Results and Discussion}

The socio-economic variables of the rice farmers which includes sex, age, household size, formal education, extension visit, years in cooperative society, rice farming experience, farm size among 
others were analyzed using percentage, mean, frequency, and standard deviation and presented in Table 1.

Table 1 shows that most (70.25\%) of the rice farmers were male while a few $(29.75 \%)$ of them were female. This shows that male was more among Ebonyi rice farmers. Age of the farmers usually affect the ability of the farmer to perform farming operation. The result shows that rice farmers' average age was 46 . This shows that most of the rice farmers are within their economic stage. Therefore, they can make positive contribution to agricultural development. This finding is in line with [20]. Table 1 reveals that the average households' size were 6 members in the Ebonyi rice farmers households, implying that majority of them have relatively high household sizes. This is a positive indication of the availability of family labour. This agrees with [21].

Education can enhance farmers' ability to make meaningful management decisions. Table 1 reveals that the average years spent in formal education were 8 years. This indicates that most of the rice farmers have some level of formal education and can therefore make effective farm management decisions. This finding agrees with [22]. Membership of a cooperative society enables farmers to relate with other farmers, and it aids in information and experiences sharing. Table 1 reveals that the average number of years spent in the cooperative society were 1.2 years. This is not adequate enough to share experiences. Through extension visits, farmers are better informed about new technologies. Table 1 result reveals that the average extension visit were 1.3 times per farming period which is not adequate enough for the extension worker to guide them through the farming period. [23] observed that regular extension contact is very essential in the adoption of improve techniques by the farmers.

The longer a farmer stay in farming, the better his performance. Table 1 reveals that the average years of rice farming experience were 23.4 years which is long enough for the rice farmer to improve their performance in rice operation. This is in line with [24]. Furthermore, Table 1 shows that most (53.31\%) of the rice farmers planted improved varieties identified as FARO 44 and FARO 52 while minority (46.69\%) of them planted local variety identified as MARS, R16 and 306.

Table 1. Socio-economics Variables of Rice Farmers in Ebonyi State

\begin{tabular}{lccc}
\hline \multicolumn{1}{c}{ Variables } & Frequency & Percentage & Value \\
\hline Sex & & & \\
- Female & 72 & 29.75 \\
- Male & 170 & 70.25 \\
- Total & 242 & 100 & \\
Age & & \\
- $21-30$ & 13 & 5.37 \\
- $31-40$ & 67 & 27.69 \\
- $41-50$ & 85 & 35.13 \\
- $51-60$ & 57 & 23.55 \\
- $71-70$ & 19 & 7.85 \\
- Total & 1 & 0.41 \\
\hline
\end{tabular}


Table 1. Continued

\begin{tabular}{|c|c|c|c|}
\hline Variables & Frequency & Percentage & Value \\
\hline \multicolumn{4}{|l|}{ Household size } \\
\hline - $1-5$ & 61 & 25.21 & \\
\hline - $6-10$ & 158 & 65.29 & \\
\hline - $11-15$ & 20 & 8.26 & \\
\hline - $16-20$ & 3 & 1.24 & \\
\hline - Total & 242 & 100 & \\
\hline - Mean & & & 7 \\
\hline - S.D & & & 2.47 \\
\hline \multicolumn{4}{|l|}{ Years in formal Education } \\
\hline - 0 & 47 & 19.42 & \\
\hline - $1-6$ & 80 & 33.06 & \\
\hline - $7-12$ & 103 & 42.56 & \\
\hline - $13-18$ & 12 & 4.96 & \\
\hline - Total & 242 & 100 & \\
\hline - Mean & & & 8 \\
\hline - S.D & & & 4.8 \\
\hline \multicolumn{4}{|l|}{ Years in cooperative } \\
\hline - 0 & 146 & 60.33 & \\
\hline - $1-10$ & 84 & 34.71 & \\
\hline - $11-20$ & 12 & 4.96 & \\
\hline - Total & 242 & 100 & \\
\hline - Mean & & & 1.2 \\
\hline - S.D & & & 1.8 \\
\hline \multicolumn{4}{|l|}{ Extension visits } \\
\hline - 0 & 114 & 47.11 & \\
\hline - $1-3$ & 128 & 52.89 & \\
\hline - Total & 242 & 100 & \\
\hline - Mean & & & 1.3 \\
\hline - S.D & & & 0.4 \\
\hline \multicolumn{4}{|l|}{ Rice farming experience } \\
\hline - $5-14$ & 38 & 15.70 & \\
\hline - $15-24$ & 107 & 44.21 & \\
\hline - $25-34$ & 55 & 22.73 & \\
\hline - $35-44$ & 35 & 14.46 & \\
\hline - $45-54$ & 7 & 2.90 & \\
\hline - Total & 242 & 100 & \\
\hline - Mean & & & 23.4 \\
\hline - S.D & & & 9.6 \\
\hline \multicolumn{4}{|l|}{ Rice variety } \\
\hline - Local & 113 & 46.69 & \\
\hline - Improved & 129 & 53.31 & \\
\hline - Total & 242 & 100 & \\
\hline \multicolumn{4}{|l|}{ Rice farm size } \\
\hline - $0.2-1.1$ & 162 & 66.94 & \\
\hline - $1.2-2.1$ & 63 & 26.03 & \\
\hline - $2.2-3.1$ & 16 & 6.61 & \\
\hline - $3.2-4.1$ & 1 & 0.41 & \\
\hline - Total & 242 & 100 & \\
\hline - Mean & & & 1.1 \\
\hline - S.D & & & 0.6 \\
\hline \multicolumn{4}{|l|}{ Land acquisition } \\
\hline - Inherited & 126 & 52.07 & \\
\hline - Rent & 97 & 40.08 & \\
\hline - Rent/inherited & 6 & 2.48 & \\
\hline - Purchase/inherited & 4 & 1.65 & \\
\hline - Purchase & 2 & 0.83 & \\
\hline - Community owned & 7 & 2.89 & \\
\hline - Total & 242 & 100 & \\
\hline
\end{tabular}


The average rice farm size were 1.1 hectares. This shows that they were mainly small holder farmers based on [25], which classified farmers with less than 5 hectares of land as small scale [25]. This conforms to [26] who found average rice farm size of 2.6 hectares. Factors like high labour cost, high land payment and low-income level of farming households could be responsible for the small rice farm size. Land acquisition by the rice farmers shows that $52.07 \%$ of them used inherited land while a lesser percentage (2.89\%) them used community owned land.

The result of the Net Farm Income and the Return on US Dollar Invested were presented in Table 2. Table 2 reveals that Ebonyi rice farmers used an average rice seed of $117.1 \mathrm{~kg} / \mathrm{ha}$, these exceeded the rate of between $50-100 \mathrm{~kg} /$ ha as recommended. The recommended rate of fertilizer is $200-250 \mathrm{~kg} / \mathrm{ha}$ of NPK. Rice farmers used an average of $145.32 \mathrm{~kg} / \mathrm{ha}$ of fertilizer, this is below the recommended rate. Nigeria recommended between $12-13$ liters of herbicides for one hectare of rice farm, but the sampled rice farmers used 2.5 liters of herbicide for one hectare. The yields obtained by the farmers were 3.496 tonnes/ha of paddy, which is below the potential yield of $5-6$ tonnes/ha using improved practice.

Also, Table 2 reveals that the total rice farming cost by the rice farmers were $\$ 484.27$ US Dollar per hectare. The total revenue/ha realized by them were $\$ 1,384.37$ US Dollar while the Net Rice Farming Income (NRFI) obtained were $\$ 900.10$ US Dollar per hectare. This shows that Ebonyi state rice production is profitable. This finding is in line with [27] that discovered a net income of $\$ 418.66$ US Dollar per hectare in paddy rice production in Kaduna state.

Table 2. Profitability of Rice Production in Ebonyi State

\begin{tabular}{lccc}
\hline \multicolumn{1}{c}{ Variable } & $\begin{array}{c}\text { Average quantity } \\
\text { Per hectare }\end{array}$ & $\begin{array}{c}\text { Unit price } \\
\text { (US Dollar) }\end{array}$ & $\begin{array}{c}\text { Average cost } \\
\text { (US Dollar) }\end{array}$ \\
\hline Fixed inputs & & & 26.10 \\
Depreciation & & & 68.72 \\
Land rent & & & 74.82 \\
Total Fixed cost & & & \\
& & & \\
Variable inputs & 140.19 & 1.99 & 278.98 \\
Labour (man-days) & 145.32 & 0.36 & 52.32 \\
Fertilizer (Kg) & 117.11 & 0.45 & 52.70 \\
Rice Seed (Kg) & 2.5 & 7.62 & 19.05 \\
Herbicide (liters) & 128.00 & $5 \%$ & 6.40 \\
Interest on loan (USD) & & & 409.45 \\
Total Variable cost & & & 484.27 \\
& & & 477.87 \\
Total cost + interest & & & 1384.37 \\
Total cost - interest & & & 1384.37 \\
Output (Kg) & $3,296.12$ & & 900.10 \\
Total Revenue (Output x price) & & & \\
NFI (GR - (TC+ interest)) & 2.90 & & \\
RUSDI ((TR/(TC) -interest) & & & \\
\hline Not The rice & & & \\
\hline
\end{tabular}

Note: The rice profitability was normalized to one hectare of rice land 
The rice farmer's return on investment were \$2.90 US Dollar. This implies that for every one US Dollar (\$1.00) invested in rice production, a profit of \$1.9 US Dollar was realized. This reveals that rice production is profitable in Ebonyi State. Therefore, investing in Ebonyi rice production is more profitable than investing in Nigerian bank through savings. This validates [28] who stated that rice production is profitable in Adamawa state.

\section{Conclusion and Recommendation}

This study on the analysis of the cost and economic returns in rice production in Ebonyi state, Nigeria concluded that Ebonyi state rice production is profitable. The farming practices (SRI) adopted by the rice farmers is of benefit. Therefore, unemployed youth in Nigeria should be encourage through provision of rice farming grant or loan by the governmental and nongovernmental agency. In addition, adequate training on improve technology should be conducted by the government agency (ADPs) for the rice farmers.

\section{REFERENCES}

[1] J. O. Nwele, "Economics of rice production and marketing in Nigeria: A study of Ebonyi State," International Journal for Research in Business, Management and Accounting, vol. 2, no. 5, pp. 17-37, 2016.

[2] O. I. Osanyinlusi and K. O. Adenegan, "The determinants of rice farmers productivity in Ekiti State, Nigeria," Greener Journal of Agricultural Science, vol. 6, no. 2, pp. 049-058.

[3] FAO, "Nigeria at a glance," Available: www.fao.org/nigeria/fao-in-nigeria/nigeria-at-aglance/en, [Accessed: 12 ${ }^{\text {th }}$ September, 2019].

[4] O. C. Nwahia, "Impact assessment of USAID-MARKETS II Project on productivity and poverty status of rice farming households in Ebonyi State, Nigeria," Ph.D. dissertation, Ahmadu Bello University, Zaria, Nigeria, 2020.

[5] C. Onyekwena, "Towards rice self-sufficiency in Nigeria: Contemporary issues and challenges," A Power Point Presentation to Centre for the Study of the Economies of Africa (CSEA), 2016.

[6] United States Department of Agriculture (USDA), "Grain: World Markets and Trade. Foreign Agricultural Services," Available: www.tralac.org/images/docs/12936/grain-worldmarkets-and-trade-usda-april-2018.pdf, [Accessed: $15^{\text {th }}$ September, 2019].

[7] International Food Policy Research Institute (IFPRI), “The Nigerian rice economy: Policy options for transforming production, marketing, and trade," edited by G. Kwabena, J. Michael, and T. Hiroyuki, University of Pennsylvania Press Philadelphia, 2016.

[8] Sahel Capital (Mauritius) Limited, "Rice in Nigeria: Industry Dynamics," Sahel Capital Partners \& Advisory Limited, vol. 12, 2015.

[9] Grow Africa, "Ecowas Rice Fact Book," The African Union Development Agency-NEPAD, 2017.

[10] A. H. Adenuga, O. A. Omotesho, R. O. Babatunde, D. P. Popooola, and G. Opeyemi, "Effect of Fadama III Programme on poverty status of rice farming households in patigi local government area of Kwara State, Nigeria," Journal of Agriculture, Forestry and the Social Sciences (JOAFSS), vol. 11, no. 2, pp. 80-91, 2013. 
[11] A. O. Oko and S. I. Ugwu, "The proximate and mineral composition of five major rice varieties in Abakaliki, South-Eastern Nigeria," International Journal of Plant Physiology and Biochemistry, vol. 3, no. 2, pp. 25-27, 2011.

[12] J. Iwuchukwu, C. Ayogu, and I. Udegbunam, "Activities of farmers in rice production in Awka North Local Government Area, Anambra State, Nigeria," Journal of Experimental Agriculture International, vol. 17, no. 2, pp. 1-10, 2017.

[13] A. L. Akinbile, O. O. Aminu, and I. G. Sokeye, "Constraints encountered in rice production by farmers in Ogun State, Nigeria," Nigerian Journal of Rural Sociology, vol. 18, no. 1, pp. $85-92,2018$.

[14] O. K. Adams, "Challenges of rice production in Nigeria: A case study of Kogi State," Journal of Food Science and Quality Management, vol. 74, pp. 14 -17, 2018.

[15] F. A. Obasi, F. U. Agbo, and C. S. Onyenekwe, "Environmental and socio-economic effects of timber harvesting in Ebonyi State, Nigeria," African Journal of Agricultural Research, vol. 10, no. 11, pp. 1233-1238, 2015.

[16] Ebonyi State ADP, "Farmers inventory file," 2018.

[17] A. A. Sani and Y. U. Oladimeji, "Determinants of Technical Efficiency Among Sorghum Farmers Under Agricultural Transformation Agenda in Gombe State, Nigeria," Nigerian Journal of Agriculture, Food and Environment, vol. 13, no. 3, pp. 122-127, 2017.

[18] Y. U. Oladimeji, Z. Abdulsalam, A. M. Ajao, S. Abdulrahman, and R. O. Abdulazeez, "Profit efficiency of broiler production among public servant household heads in Kwara State, Nigeria: A Coping Strategy," Asian Journal of Economics, Business and Accounting, vol. 2, no. 2, pp. 1-8, 2017.

[19] A. R. Durga and D. K. Suresh, "Economic analysis of the system of rice intensification: evidence from Southern India," Bangladesh Development Studies, vol. 36, no. 1, pp. 2013.

[20] V. A. Eze, N. E. Odoh, O. E. Igwe, and C. J. Mgbanya, "Socio-economic factors influencing poverty among rural households in onicha local government area, Ebonyi State, Nigeria," International Journal of Agricultural Research Innovation and Technology, vol. 9, no. 1, pp. $8-13,2019$.

[21] C. K. Osondu, J. C. Ijioma, S. C. Udah, and C. O. Emerole, "Impact of National Fadama III Development Project in alleviating poverty of food crop farmers in Abia State, Nigeria," American Journal of Business, Economics and Management 2015, vol. 3, no. 4, pp. 225-233, 2015.

[22] S. T. Folorunso, "Impact of Fadama III on productivity, food security and poverty status of Tuber farmers in central state of Nigeriam" Ph.D. dissertation, Ahmadu Bello University, Zaria, Nigeria, 2015.

[23] S. I. Umar, M. A. Ndanitsa, and S. R. Olaleye, "Adoption of improved rice technologies among youth farmers in Gbako Local Government Area, Niger State," Journal of Agricultural Extension, vol. 13, no. 1, pp. 1-8, 2009.

[24] A. A. Girei, N. D. Saingbe, M. A. Bitrus, and I. H. Bassey, "Revealing the impact of Fadama III Project on the income level of beneficiary farmers in Plateau State, Nigeria," European Journal of Academic Essays, vol. 4, no. 2, pp. 26-38, 2017.

[25] Federal Ministry of Agriculture and Rural Development (FMARD), "National Agriculture and Food Security Strategy, 2010-2020,” Abuja, Nigeria, 25th August, 2010.

[26] I. Y. Ilu, "Value chain analysis of rice (oryza sativa) in kano river irrigation project (krip) Kano State, Nigeria," Ph.D. dissertation, Ahmadu Bello University, Zaria, Nigeria, 2015.

[27] G. N. Ben-Chendo, N. Lawal, and M. N. Osuji, "Cost and returns of paddy rice production in Kaduna State," European Journal of Agriculture and forestry Research, vol. 5, no. 3, pp. 41-48, 2017. 
[28] A. Girei, I. S. Usman, and E. G. Onuk, "Profitability investigation of rice production in Fufore local government area of Adamawa State, Nigeria," European Journal of Academic Essays, vol. 3, no. 3, pp. 137-140, 2016. 